\title{
Efficient Suzuki-Miyaura Coupling of Deactivated Aryl Chlorides Catalyzed by an Oxime Palladacycle
}

\author{
Diego A. Alonso, * J. F. Cívicos, Carmen Nájera* \\ Departamento de Química Orgánica, Facultad de Ciencias and Instituto de Síntesis Orgánica (ISO), Alicante University, \\ Apdo. 99, 03080 Alicante, Spain \\ Fax +34(96)5903549; E-mail: diego.alonso@ua.es; E-mail: cnajera@ua.es \\ Received 21 August 2009
}

\begin{abstract}
Aryl chlorides are efficiently cross-coupled with aryl boronic acids using $0.25 \mathrm{~mol} \%$ of $4,4^{\prime}$-dichlorobenzophenone oxime derived palladacycle as precatalyst in the presence of 60.50 hol\% of $\left[\mathrm{HP}(t-\mathrm{Bu})_{3}\right] \mathrm{BF}_{4}$ as ligand, $\mathrm{K}_{2} \mathrm{CO}_{3}$ as base, $\mathrm{TBAOH}$ as additive, and DMF as solvent under conventional thermal or MW irradiation conditions. Under these simple reaction conditions a wide array of deactivated and hindered aryl chlorides react cleanly to afford in high yields functionalized biaryl derivatives.
\end{abstract}

Key words: palladacycles, boronic acids, cross-coupling, biaryls, Suzuki reaction

Biaryl derivatives are important substructures in fine chemistry and are of industrial interest in a wide range of applications, including the synthesis pharmaceuticals, herbicides, polymers, materials, liquid crystals, and efficient ligands for catalysis. ${ }^{1}$ The palladium-catalyzed $\mathrm{Su}-$ zuki-Miyaura coupling is certainly one of the most attractive methods for preparing biaryl compounds thanks to the functional-group tolerance of the reaction, the use of stable and nontoxic organoborane reagents, and the possibility of using water or aqueous solvents as reaction medium. ${ }^{2}$ Despite their lack of reactivity, aryl chlorides are very interesting substrates from an industrial point of view as they are cheaper and readily accessible. Nowadays, a plethora of Pd-catalyst systems are accessible for achieving the Suzuki reaction with activated aryl chlorides. However, few catalytic systems are capable of performing the Suzuki coupling of challenging deactivated aryl chlorides in good yields under low-catalyst-loading conditions. Among them, those involving electronically rich and sterically hindered trialkyl- and aryldialkylphosphanes ${ }^{3,4}$ and heterocyclic or carbocyclic carbenes $^{5,6}$ have been the most employed catalytic systems so far. Palladacycles ${ }^{7}$ have also been shown to be efficient precatalysts for the Suzuki coupling of aryl chlorides, especially in combination with phosphanes ${ }^{8}$ or $\mathrm{N}$-heterocyclic carbenes ${ }^{9}$ as ancillary ligands. We recently described the high catalytic activity of palladacycles $1-$ $\mathbf{3}$ in different $\mathrm{Pd}$-catalyzed cross-coupling reactions in organic and aqueous solvents. ${ }^{10}$ In particular, palladacycle 1 is a very active precatalyst for the Suzuki reaction of aryl bromides and activated aryl chlorides in a 95:5 mixture of

SYNLETT 2009, No. x, pp 0001-0005

Advanced online publication: xx.xx.2009

DOI: 10.1055/s-0029-xxxxx; Art ID: G2730gsT

(c) Georg Thieme Verlag Stuttgart . New Y ork

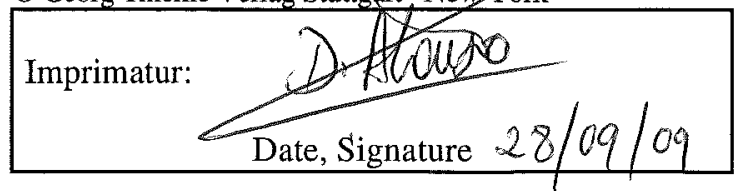

DMF- $\mathrm{H}_{2} \mathrm{O}$ as solvent at $130{ }^{\circ} \mathrm{C}$ with TONs of up to $4700 .{ }^{11}$ Unfortunately, palladacycle $1(0.5 \mathrm{~mol} \% \mathrm{Pd})$ has shown very low reactivity with unactivated aryl chlorides such as 4-chlorotoluene and 4-chloroanisole affording low yields ( $28 \%$ and $40 \%$, respectively) even working under harsh reaction conditions (DMF, $\left.160{ }^{\circ} \mathrm{C}\right) .{ }^{11 \mathrm{~b}}$ On the other hand, catalysts $2^{12 a, b}$ and $3^{12 c}$ are very active precatalysts for the coupling of arylboronic acids with aromatic and heteroaromatic bromides and chlorides in water under reflux conditions or at room temperature in aqueous $\mathrm{MeOH}$. Here, as a part of our ongoing research program on Suzuki coupling reactions catalyzed by oxime palladacycles, we report a large improvement of the catalytic activity of oxime palladacycle 1 in the Suzuki coupling of aryl chlorides with aryl boronic acids in organic solvents by using tetrabutylammonium hydroxide as cocatalyst and tri-tert-butylphosphane as ancillary ligand under thermal and microwave ${ }^{13}$ irradiation conditions.<smiles></smiles>

Figure 1 Oxime palladacycles

The assessment of the efficiency of a catalytic system is its performance with challenging substrates. Thus, optimization of the reaction conditions were performed under MW irradiation conditions $\left(40 \mathrm{~W}, 130^{\circ} \mathrm{C}, 20 \mathrm{~min}\right.$ ) with the exigent 4-chloroanisole and phenylboronic acid using $0.25 \mathrm{~mol} \%$ of catalyst 1 (Scheme 1 , Table 1 ).

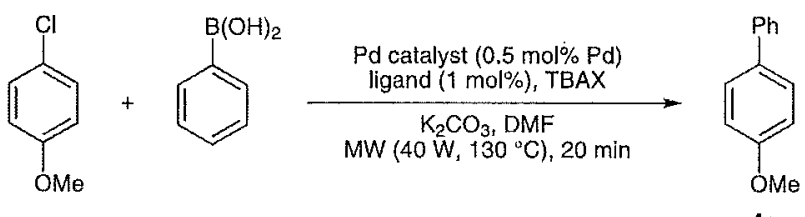

$4 a$

Scheme 1 Suzuki coupling of 4-chloroanisole with phenylboronic acid 
Using the same reaction conditions as for aryl bromides and activated aryl chlorides, ${ }^{11}$ that is, $\mathrm{K}_{2} \mathrm{CO}_{3}$ as base, tetrabutylammonium bromide (TBAB) as additive in DMF as solvent, palladacycle 1 was not so efficient and 4-methoxybiphenyl was obtained in only $19 \%$ conversion (Table 1 entry 1). The presence of $\mathrm{Ph}_{3} \mathrm{P}$ as ligand (1 mol\%) was even deleterious for the process since no cross-coupled product was observed after 20 minutes (Table 1 , entry 2). The catalytic activity of palladacycle 1 was also studied in the presence of different dialkylbiaryl phosphane ligands such as 2-(biphenyl)dicyclohexylphosphane, 2-dicyclohexylphosphino-2',4',6'-triisopropylbiphenyl (Xphos), and 2-dicyclohexylphosphino-2' ( $N, N$-dimethylamino)biphenyl (DavePhos) ${ }^{3 \mathrm{~b}}$ (Table 1, entries 3-5), obtaining the best result with the latter as ancillary ligand ( $21 \%$ conversion, entry 5$)$. The reaction seemed to fail under MW heating when bulky and electron-rich ligands, since when using 1,3,5-triaza-7-phosphadamantane and tricyclohexyl phospane less than $10 \%$ conversion of 4-methoxybiphenyl was obtained in both cases (Table 1, entries 6 and 7). However, the employment of tri-tert-butyl phosphane led to a significant increase of the catalyst efficiency affording a $32 \%$ conversion in the process (entry 8). This conversion could be greatly improved by using the more robust and stable tri-tert-butylphosphonium tetrafluoroborate ${ }^{14}$ as ligand, which, under the basic reaction conditions, afforded $\mathbf{4 a}$ in a $40 \%$ isolated yield (Table 1, entry 9). In contrast, bidentate phosphane ligands such as 1,1'-bis(diisopropylphosphino)ferrocene (DIPPF) and 4,5bis(diphenylphosphino)-9,9-dimethylxanthene (Xantphos) gave product $\mathbf{4 a}$ in very low conversions under the same reaction conditions (Table 1 , entries 10 and 11). Very low conversions were also obtained when other types of ligands such as tris(2,4-di-tert-butylphenyl)phosphite and 1,3-bis(2,6-diisopropylphenyl)imidazolinium chloride were used, affording compound $\mathbf{4 a}$ in very low conversions (Table 1, entries 12 and 13).

Table 1 Optimization of the Reaction Conditions $\mathrm{s}^{\mathrm{a}}$

\begin{tabular}{|c|c|c|c|c|}
\hline Entry & Pd catalyst & Ligand & Cocatalyst (20 mol\%) & Conversion $(\%)^{\mathrm{b}}$ \\
\hline 1 & $\mathbf{1}$ & - & $\mathrm{TBAB}$ & $1 p=01$ \\
\hline 2 & 1 & $\mathrm{Ph}_{3} \mathrm{P}$ & TBAB & $<5$ \\
\hline 3 & 1 & 2-(biphenyl)dicyclohexylphosphane & $\mathrm{TBAB}$ & $<5$ \\
\hline 4 & 1 & Xphos & TBAB & 19 \\
\hline 5 & 1 & Davephos & TBAB & 21 \\
\hline 6 & 1 & 1,3,5-triaza-7-phosphadamantane & $\mathrm{TBAB}$ & $<5$ \\
\hline 7 & 1 & $\mathrm{Pcy}_{3}$ & $\mathrm{TBAB}$ & 5 \\
\hline 8 & 1 & $\mathrm{P}(t-\mathrm{Bu})_{3}$ & TBAB & 32 \\
\hline 9 & 1 & {$\left[\mathrm{HP}(t-\mathrm{Bu})_{3}\right] \mathrm{BF}_{4}$} & $\mathrm{TBAB}$ & $81(40)$ \\
\hline 10 & 1 & DIPPF & $\mathrm{TBAB}$ & 8 \\
\hline 11 & 1 & Xantphos & TBAB & $<5$ \\
\hline 12 & 1 & tris(2,4-di-tert-butylphenyl)phosphite & TBAB & 22 \\
\hline 13 & 1 & 1,3-bis(2,6-diisopropylphenyl)imidazolinium chloride & TBAB & 14 \\
\hline 14 & 1 & {$\left[\mathrm{HP}(t-\mathrm{Bu})_{3}\right] \mathrm{BF}_{4}$} & TBAOH & $>95(74)$ \\
\hline 15 & $\mathbf{1}^{\mathrm{c}}$ & {$\left[\mathrm{HP}(t-\mathrm{Bu})_{3}\right] \mathrm{BF}_{4}$} & TBAOH & $(60)$ \\
\hline 16 & $\mathbf{1}^{\mathrm{d}}$ & {$\left[\mathrm{HP}(t-\mathrm{Bu})_{3}\right] \mathrm{BF}_{4}$} & TBAOH & $>95(93)$ \\
\hline 17 & $\mathbf{1}^{\mathrm{e}}$ & {$\left[\mathrm{HP}(t-\mathrm{Bu})_{3}\right] \mathrm{BF}_{4}$} & TBAOH & 17 \\
\hline 18 & $2^{\mathrm{d}}$ & {$\left[\mathrm{HP}(t-\mathrm{Bu})_{3}\right] \mathrm{BF}_{4}$} & $\mathrm{TBAOH}$ & $(57)$ \\
\hline 19 & $\mathrm{Pd}(\mathrm{OAc})_{2}{ }^{\mathrm{d}}$ & {$\left[\mathrm{HP}(t-\mathrm{Bu})_{3}\right] \mathrm{BF}_{4}$} & TBAOH & $(47)$ \\
\hline
\end{tabular}

${ }^{a}$ A $10 \mathrm{~mL}$ microwave vessel was charged with $\mathrm{K}_{2} \mathrm{CO}_{3}(1.5 \mathrm{mmol}, 207 \mathrm{mg})$, TBAOH $(0.15 \mathrm{mmol}, 120 \mathrm{mg}), \mathrm{PhB}(\mathrm{OH}){ }_{3}(1.88 \mathrm{mmol}, 225 \mathrm{mg})$ Pd catalyst $(0.0019 \mathrm{mmol}, 0.5 \mathrm{~mol} \% \mathrm{Pd}),\left[\mathrm{HP}(t-\mathrm{Bu})_{3}\right] \mathrm{BF}_{4}(0.00375 \mathrm{mmol}, 11 \mathrm{mg}), 4$-chloroanisole $(0.75 \mathrm{mmol}, 92 \mathrm{~h}$ 的), and DMF $(1.5 \mathrm{~mL})$. The vessel was sealed with a pressure lock, and the mixture was heated in air at $130^{\circ} \mathrm{C}$ by a MW irradiation of $40 \mathrm{~W}$ for $20 \mathrm{~min}$.

${ }^{b}$ Conversion to coupled product determined by GC using decane as internal standard. In parentheses, isolated yield after recrystallization in $\mathrm{MeOH}-\mathrm{H}_{2} \mathrm{O}(3: 1)$.

${ }^{\circ}$ The reaction was carried out under conventional heating conditions at $160{ }^{\circ} \mathrm{C}$ for $24 \mathrm{~h}$.

${ }^{d}$ Conditions: $0.1 \mathrm{~mol} \%$ of $\mathrm{Pd}$ and $0.2 \mathrm{~mol} \%$ of $\left[\mathrm{HP}(t-\mathrm{Bu})_{3}\right] \mathrm{BF}_{4}$

${ }^{\mathrm{e}}$ Conditions: $0.01 \mathrm{~mol} \%$ of $\mathrm{Pd}$ and $0.02 \mathrm{~mol} \%$ of $\left[\mathrm{HP}(t-\mathrm{Bu})_{3}\right] \mathrm{BF}_{4}$. 
Once determined that tri-tert-butylphosphonium tetrafluoroborate was the ligand of choice for the Suzuki coupling of 4-chloroanisol and phenylboronic acid, further reaction-conditions optimization was carried out in order to improve the efficiency of the catalytic system. Quantitative conversion and a $74 \%$ isolated yield after recrystallization were obtained when a $20 \mathrm{~mol} \%$ of tetrabutylammonium hydroxide (TBAOH) was used instead of TBAB as additive (Table 1, compare entries 9 and 14) ${ }^{15}$ At this point, the efficiency of the $\mathrm{MW}$ protocol was demonstrated by performing the cross-coupling under conventional heating conditions at $160^{\circ} \mathrm{C}$ obtaining, after 24 hours, a $60 \%$ isolated yield of $\mathbf{4 a}$ (entry 15 ). In order to test the limits of the system under the optimized reaction conditions, the precatalyst loading was decreased to $0.1 \mathrm{~mol} \%$ of Pd affording an excellent $93 \%$ isolated yield of 4-methoxybiphenyl after 20 minutes at $130{ }^{\circ} \mathrm{C}$ (Table 1, entry 16). Unfortunately, only a $17 \%$ conversion could be achieved reducing the loading down to $10^{-2}$ mol\% of Pd (Table 1, entry 17). The catalytic activity of

Table 2 Suzuki Synthesis of Biaryls from Aryl Chlorides Catalyzed by 1 under MW (A) and Thermal (B) Reaction Conditions

\begin{tabular}{|c|c|c|c|c|c|}
\hline \multirow[t]{2}{*}{ Entry } & \multirow[t]{2}{*}{$\mathrm{ArCl}$} & \multirow[t]{2}{*}{ Product } & \multirow[t]{2}{*}{ No. } & \multicolumn{2}{|c|}{ Yield $(\%)^{\mathrm{a}}$} \\
\hline & & & & $\mathbf{A}$ & B \\
\hline 1 & & & $4 b$ & $78 \%$ & $>99 \mathrm{f}$ \\
\hline 2 & & & $4 c$ & $>99 / \mathrm{c}$ & $90 /$ \\
\hline 3 & & & $4 a$ & $74^{b}$ & $60^{\mathrm{b}}$ \\
\hline 4 & & & $4 d$ & 93 & 77) \\
\hline 5 & & & $4 e$ & $83 t$ & $85 /$ \\
\hline 6 & & & $4 f$ & $87^{\mathrm{b}}$ & $84^{b}$ \\
\hline 7 & & & $4 g$ & $68^{b, c}$ & $65^{\mathrm{b}}$ \\
\hline 8 & & & $4 h$ & $67 \mathrm{kc}$ & 87 \\
\hline 9 & & & $4 i$ & $62 / c$ & 52 \\
\hline 10 & & & $4 \mathbf{j}$ & $82^{\mathrm{d}}$ & $64^{\mathrm{d}}$ \\
\hline 11 & & & $4 k$ & $80^{d}$ & $59^{d}$ \\
\hline 12 & & & 41 & $70 \%$ & 31) \\
\hline 13 & & & $4 m$ & $77 \mid$ & 72 \\
\hline
\end{tabular}

a Isolated yield after flash chromatography.

${ }^{\mathrm{b}}$ Isolated yield after recrystallization in $\mathrm{MeOH}-\mathrm{H}_{2} \mathrm{O}(3 ; 1)$.

${ }^{\mathrm{c}}$ Reaction time: $40 \mathrm{~min}$.

${ }^{\mathrm{d}}$ Isolated yield after recrystallization in $\mathrm{Et}_{2} \mathrm{O}$-hexane. 
palladacycle 1 was compared with palladacycle 2 (Figure 1) and $\mathrm{Pd}(\mathrm{OAc})_{2}$ under the optimized low loading conditions ( $0.1 \mathrm{~mol} \% \mathrm{Pd}$ ). As depicted in Table 1 (entries 18 and 19) both catalysts presented lower activity in the cross-coupling reaction giving $\mathbf{4 a}$ in $57 \%$ and $47 \%$ isolated yield, respectively.

Different activated and deactivated aryl chlorides and heterocyclic derivatives were cross-coupled with arylboronic acids under the MW optimized reaction conditions (Scheme 2, Table 2, conditions A): palladacycle $1(0.25$ $\mathrm{mol} \%)$ and $\left[\mathrm{HP}(t-\mathrm{Bu})_{3}\right] \mathrm{BF}_{4}(1 \mathrm{~mol} \%)$ as catalytic mixture, TBAOH (20 mol\%) as additive, and $\mathrm{K}_{2} \mathrm{CO}_{3}$ as base in DMF at $130^{\circ} \mathrm{C}(\mathrm{MW}, 40 \mathrm{~W}, 2.41 \mathrm{bar}, 20 \mathrm{~min})$. The reactions were also carried out under conventional heating at $160{ }^{\circ} \mathrm{C}$ for 24 hours (Scheme 2, Table 2, conditions B). With the purpose of comparison, the same catalyst loading $(0.5 \mathrm{~mol} \% \mathrm{Pd})$ was used under both reaction conditions. The process was very effective for the coupling of sterically hindered activated aryl chlorides such as 2-chlorobenzonitrile (Table 2, entries 1,2 ). This substrate reacted very efficiently with phenyl- and 4-tolylboronic acids, producing with the latter 2-cyano-4'-methylbiphenyl (4c), a key intermediate in the synthesis angiotensin II receptor antagonists that are used for the treatment of hypertension. $^{16}$

$$
\begin{aligned}
& 1(0.5 \mathrm{~mol} \% \mathrm{Pd}) \\
& {\left[\mathrm{HP}(\mathrm{t}-\mathrm{Bu})_{3}\right] \mathrm{BF} \mathrm{F}_{4}(1 \mathrm{~mol} \%) \text {, }} \\
& \mathrm{ArCl}+\mathrm{Ar}^{\prime} \mathrm{B}(\mathrm{OH})_{2} \frac{\mathrm{TBAOH}(20 \mathrm{~mol} \%), \mathrm{K}_{2} \mathrm{CO}_{3}, \mathrm{DMF}}{\mathrm{A}: \mathrm{MW}\left(40 \mathrm{~W}, 130^{\circ} \mathrm{C}\right), 20 \mathrm{~min}} \mathrm{Ar}-\mathrm{Ar}^{\prime} \\
& \begin{array}{l}
\text { A: } M W\left(40 W, 130^{\circ} \mathrm{C}\right), 20 \mathrm{~min} \\
\text { B: } 160^{\circ} \mathrm{C}, 24 \mathrm{~h}
\end{array}
\end{aligned}
$$

Scheme 2 Suzuki synthesis of biaryls from aryl chlorides

With respect to deactivated aryl chlorides, microwave irradiation and conventional heating afforded, in general, high yields for the corresponding biaryl derivatives after purification by flash chromatography or recrystallization (Table 2, entries 3-10). ${ }^{17}$ Besides phenylboronic acid, 4chloroanisole efficiently reacted under MW and conventional heating conditions, with 4-fluorophenyl- and 4-(trifluoromethyl)phenylboronic acids, affording the corresponding biaryl derivatives in high yields (Table 2, entries 4 and 5). Good yields were also obtained with other electron-rich aryl chlorides such as 4-chlorotoluene, 4 chlorophenol, and 4-chloroaniline. These deactivated substrates afforded compounds $\mathbf{4 f}, \mathbf{4 g}$, and $\mathbf{4 h}$, respectively with isolated yields ranging from $65 \%$ to $87 \%$ (Table 2 , entries 6-8). In the more sterically demanding coupling reaction of 2-chloro-1,3-dimethylbenzene with phenylboronic acid, the product was obtained in moderate yields under MW and conventional heating reaction conditions (Table 2, entry 9). On the other hand, MW heating was very effective for the synthesis of biphenylacetic and 4phenylmandelic acids, very interesting substrates from the pharmaceutical point of view. ${ }^{18}$ These derivatives were prepared from the corresponding chloride precursors in $82 \%$ and $80 \%$ yield, respectively (Table 2, entries 10 and
11). Conventional heating afforded the products in significantly lower yields. The examples illustrated in Table 2 with 2-chloropyridine and 2-chlorothiophene (entries 12 and 13 , respectively), clearly show these heterocycles to be tolerated and compatible with the present method as high yields of the corresponding coupling products (particularly for MW conditions) were obtained.

In summary, catalyst formed in situ from readily available and easily handled oxime palladacycle $\mathbf{1}$ and tri-tert-butylphosphonium tetrafluoroborate under basic conditions shows very good activity in the Suzuki coupling of activated and deactivated aryl chlorides under MW and conventional heating employing TBAOH as cocatalyst and DMF as solvent. Currently, further studies are under way addressing extension of this catalytic system to other palladium-catalyzed transformations.

\section{Acknowledgment}

Financial support from the MEC (Projects CTQ2004-00808/BQU, CTQ2007-62771/BQU and Consolider INGENIO 2010 CSD200700006), from the Generalitat Valenciana (Projects GV/2007/142 and PROMETEO/2009/03 $\$$, and the University of Alicante is acknowledged.

\section{References and Notes}

(1) (a) Littke, A. In Modern Arylation Methods; Ackermann, L., Ed.; Wiley-VCH: Weinheim, 2009, 25. (b) Catellani, M.; Motti, E.; Della Ca', N.; Ferraccioli, R. Eur. J. Org. Chem. 2007, 4153. (c) Alberico, D.; Scott, M. E.; Lautens, M. Chem. Rev. 2007, 107, 174. (d) Suzuki, A. In Boronic Acids. Preparation, Applications in Organic Synthesis and Medicine; Hall, D. G., Ed.; Wiley-VCH: Weinheim, 2005, 123.

(2) For recent selected reviews, see: (a) Alonso, F.; Beletskaya, I. P.; Yus, M. Tetrahedron 2008, 64, 3047. (b) Miyaura, N. In Metal-Catalyzed Cross-Coupling Reactions, 2nd ed., Vol. 1; de Meijere, A.; Diederich, F., Eds.; Wiley-VCH: Weinheim, 2004, 41.

(3) For recent reviews, see: (a) Martin, R.; Buchwald, S. L. Acc. Chem. Res. 2008, 41, 1461. (b) Fu, G. C. Acc. Chem. Res. $2008,41,1555$.

(4) For representative examples, see: (a) Littke, A. F.; Dai, C.; Fu, G. C. J. Am. Chem. Soc. 2000, 122, 4020. (b) Zapf, A.; Ehrentraut, A.; Beller, M. Angew. Chem. Int. Ed. 2000, 39 , 4153. (c) Walker, S. D.; Barder, T. E.; Martinelli, J. R.; Buchwald, S. L. Angew. Chem. Int. Ed. 2004, 43, 1871.

(5) For recent reviews, see: (a) Marion, N.; Nolan, S. P. Acc. Chem. Res. 2008, 41, 1440. (b) Würtz, S.; Glorius, F. Acc. Chem. Res. 2008, 41, 1523. (c) Organ, M. G.; Chass, G. A.; Fang, D.-C.; Hopkinson, A. C.; Valente, C. Synthesis 2008, 2776. (d) Kantchev, E. A. B.; O'Brien, C. J.; Organ, M. G. Angew. Chem. Int. Ed. 2007, 46, 2768.

(6) For representative examples, see: (a) Gstöttmayr, C. W. K. Böhm, V.P. W.; Herdtweck, E.; Grosche, M.; Herrmann, W. A. Angew. Chem. Int. Ed. 2002, 41, 1363. (b) Herrmann, W. A.; Öfele, K.; Schneider, S. K.; Herdtweck, E.; Hoffmann, S. D. Angew. Chem. Int. Ed. 2006, 45, 3859. (c) Diebolt, O.; Braunstein, P.; Nolan, S. P.; Cazin, C. S. J. Chem. Commun. 2008, 3190. (d) Organ, M. G.; Çalimsiz, S.; Sayah, M.; Hoi, K. H.; Lough, A. J. Angew. Chem. Int. Ed. 2009, 48, 2383. 
(7) Palladacycles: Synthesis, Characterization and Applications; Dupont, J.; Pfeffer, M., Eds.; Wiley-VCH: Weinheim, 2008.

(8) (a) Bedford, R. B.; Cazin, C. S. J. Chem. Commun. 2001, 1540. (b) Schnyder, A.; Indolese, A. F.; Studer, M.; Blaser, H.-U. Angew. Chem. Int. Ed. 2002, 41, 3668. (c) Bedford, R. B.; Cazin, C. S. J.; Hazelwood, S. L. Angew. Chem. Int. Ed. 2002, 41, 4120.

(9) Navarro, O.; Kelly, R. A.; Nolan, S. P. J. Am. Chem. Soc. 2003, 125, 16194.

(10) Alacid, E.; Alonso, D. A.; Botella, L.; Nájera, C.; Pacheco, M. C. Chem. Rec. 2006, 6, 117.

(11) (a) Alonso, D. A.; Nájera, C.; Pacheco, M. C. Org. Lett. 2000, 2, 1823. (b) Alonso, D. A.; Nájera, C.; Pacheco, M. C. J. Org. Chem. 2002, 67, 5588.

(12) (a) Botella, L.; Nájera, C. Angew. Chem. Int. Ed. 2002, 41, 179. (b) Botella, L.; Nájera, C. J. Organomet. Chem. 2002, 663, 46. (c) Alacid, E.; Nájera, C. J. Organomet. Chem. 2009, 694, 1658.

(13) Appukkuttan, P.; Van der Eyken, E. Eur. J. Org. Chem. 2008, 1133.

(14) Netherton, M. R.; Fu, G. C. Org. Lett. 2001, 3, 4295.

(15) At this point, the efficiency of the previously tested phosphane ligands with TBAOH as additive was tested again, showing in all cases lower activities. For example, $\mathrm{P}(t-\mathrm{Bu})_{3}$ only led to a $31 \%$ isolated yield of $\mathbf{4 a}$.

(16) Goubet, D.; Meric, P.; Dormoy, J.-R.; Moreau, P. J. Org. Chem. 1999, 64, 4516.

(17) Typical Procedure for the Suzuki Coupling under MW Irradiation Conditions (Table 2, Entry 3)

A freshly stock soln of catalyst $1(150 \mu \mathrm{g}, 0.019 \mathrm{mmol})$ in
$\operatorname{DMF}(2.5 \mathrm{~mL})$ and $\left[\mathrm{HP}(t-\mathrm{Bu})_{3}\right] \mathrm{BF}_{4}(110 \mathrm{~g}, 0.0375 \mathrm{mmol})$ in DMF $(2.5 \mathrm{~mL})$ were previously prepared and used. A $10 \mathrm{~mL}$ MW vessel was charged with $\mathrm{K}_{2} \mathrm{CO}_{3}(1.5 \mathrm{mmol}, 207 \mathrm{mg})$, TBAOH $(0.15 \mathrm{mmol}, 120 \mathrm{mg}), \mathrm{PhB}(\mathrm{OH})_{2}(1.88 \mathrm{mmol}, 225$ $\mathrm{mg}$ ), catalyst $1(250 \mu \mathrm{L}$ of the stock soln, $0.0019 \mathrm{mmol}, 15$ $\mu \mathrm{g}, 0.5 \mathrm{~mol} \% \mathrm{Pd}),\left[\mathrm{HP}(t-\mathrm{Bu})_{3}\right] \mathrm{BF}_{4}(250 \mu \mathrm{L}$ of the stock soln, $0.00375 \mathrm{mmol}, 11 \mu \mathrm{g})$, 4-chloroanisole $(0.75 \mathrm{mmol}, 92 \mu \mathrm{L})$, and DMF $(1.5 \mathrm{~mL})$. The vessel was sealed with a pressure lock, and the mixture was heated in air at $130^{\circ} \mathrm{C}$ by a MW irradiation of $40 \mathrm{~W}$ for $20 \mathrm{~min}$ in a CEM Discover MW reactor. After allowing the reaction to cool down to r.t., the mixture was filtered through a pad of Celite and poured into an excess of $\mathrm{H}_{2} \mathrm{O}(5 \mathrm{~mL})$ and extracted with $\mathrm{Et}_{2} \mathrm{O}(3 \times 5 \mathrm{~mL})$. The combined organic phases were washed with $\mathrm{H}_{2} \mathrm{O}(3 \times 5$ $\mathrm{mL})$, dried $\left(\mathrm{MgSO}_{4}\right)$, and evaporated. The obtained crude product was purified by recrystallization in $\mathrm{MeOH}-\mathrm{H}_{2} \mathrm{O}$ (3:1), yielding $102 \mathrm{mg}$ of pure 4-methoxybiphenyl (4a, $74 \%$ ) as a white solid; $\mathrm{mp} 89-93^{\circ} \mathrm{C} .{ }^{1} \mathrm{H}$ NMR $\left(300 \mathrm{MHz}, \mathrm{CDCl}_{3}\right)$ : $\delta=7.57-7.51(\mathrm{~m}, 4 \mathrm{H}, \mathrm{ArH}), 7.42(\mathrm{t}, J=7.5 \mathrm{~Hz}, 2 \mathrm{H}, \mathrm{ArH})$, $7.30(\mathrm{t}, J=7.2 \mathrm{~Hz}, 1 \mathrm{H}, \mathrm{ArH}), 6.98(\mathrm{~d}, J=8.7 \mathrm{~Hz}, 2 \mathrm{H}, \mathrm{ArH})$, $3.86(\mathrm{~s}, 3 \mathrm{H}, \mathrm{CHO})$. MS (EI, $70 \mathrm{eV}): \mathrm{m} / z(\%)=184(100)$ $\left[\mathrm{M}^{+}\right], 169(49)\left[\mathrm{M}^{+}-\mathrm{Me}\right], 141(49), 139$ (13), 115 (35).

(18) (a) $p$-Biphenylacetic acid(felbinac) and 2-ethyl-4biphenylacetic acid with dimethylaminoethanol(namoxyrate) are anti-inflamatory and analgesic drugs, respectively: USP Dictionary of USAN and International Drugs names. (b) $\rho^{\text {Biphenylacetamides }}$ have been used as mesogenic arms porphyrin thermotropic liquid crystals: Michaeli, S.; Hugerat, M.; Levanon, H.; Bernitz, M.; Natt, A.; Neumann, R. J. Am. Chem. Soc. 1992, 114, 3612.

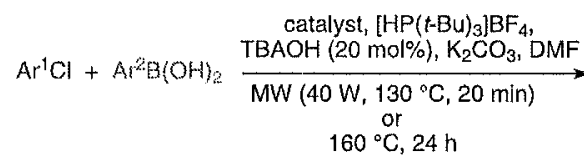

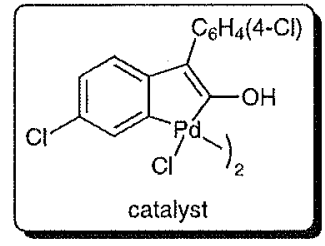

graphical abstract 